\title{
PENGARUH KOMIK ISI PIRINGKU TERHADAP ASUPAN KARBOHIDRAT DAN PROTEIN PADA ANAK GIZI LEBIH
}

\author{
Joyeti Darni ${ }^{1 *}$ dan Eva Agustina ${ }^{1}$ \\ ${ }^{1}$ Jurusan Gizi, Poltekkes Kemenkes Mataram, Indonesia \\ Jalan Praburangkasari Dasan Cermen, Sandubaya Kota Mataram \\ Email : ummunailah21@gmail.com
}

\begin{tabular}{l}
\hline \hline Article Info \\
\hline Article history: \\
Received January $2^{\text {th }}, 2020$ \\
Revised February $5^{\text {th }}, 2020$ \\
Accepted March $30^{\text {th }}, 2020$ \\
\hline
\end{tabular}

\section{Keyword:}

Carbohydrate; Comic; Isi piringku; Protein

\begin{abstract}
Background: Communication, Information and Education (IEC) of nutrition for school children can shape children's eating habits from an early age in order to achieve a better individual situation in the future. Comics are able to display simple stories and writing in colloquial so that they are easy to understand.
\end{abstract}

Research Methods. This is a quasi experimental study with control group pretest-posttest design. Subjects were taken with a simple random sample of 60 students who were divided into two groups, the first group was given education with comic Isi Piringku and the second group was given education without comic Isi Piringku. The carbohydrate and protein intake data in two groups were analyzed using the paired t-test.

Research Result. The analysis showed that the highest protein intake enhancement occurred in the treatment group with a delta of $16.7 \mathrm{~g}$, while the control group was 6.2 points. The carbohydrate intake before treatment was 191,9 $\mathrm{g}$ and increased after given comic Isi Piringku by 193,4 g. The results of different test showed that there were significant differences in the enhancement of protein intake before and after the provision of nutrition education between the control group and the treatment group with $p$ value <0.05, carbohydrate intake was not significantly different before and after treatment.

\footnotetext{
ABSTRAK

Latar Belakang : Komunikasi, Informasi dan Pendidikan tentang gizi untuk anak-anak sekolah dapat membentuk kebiasaan makan anak-anak sejak usia dini untuk mencapai kondisi individu yang lebih baik di masa depan. Komik mampu menampilkan cerita-cerita sederhana dan menulis dalam bahasa sehari-hari sehingga mudah dimengerti.

Metode penelitian : Ini adalah penelitian eksperimental semu dengan kelompok kontrol pretest-posttest design. Subjek diambil dengan sampel acak sederhana sebanyak 60 siswa yang dibagi menjadi dua kelompok, kelompok pertama diberi edukasi dengan komik Isi Piringku dan kelompok kedua diberi edukasi tanpa komik Isi Piringku. Data asupan karbohidrat dan protein dalam dua kelompok dianalisis menggunakan uji paired t-test.

Hasil penelitian : Analisis menunjukkan bahwa peningkatan asupan protein tertinggi terjadi pada kelompok perlakuan dengan delta 16,7 $\mathrm{g}$, sedangkan kelompok kontrol adalah 6,2 g. Asupan karbohidrat sebelum pengobatan adalah $191,9 \mathrm{~g}$ dan meningkat setelah diberi komik Isi Piringku sebesar 193,4 g. Hasil uji yang berbeda menunjukkan bahwa ada perbedaan yang signifikan dalam
} 
peningkatan asupan protein sebelum dan sesudah pemberian pendidikan gizi antara kelompok kontrol dan kelompok perlakuan dengan nilai $p<0,05$, asupan karbohidrat tidak berbeda secara signifikan sebelum dan sesudah perlakuan.

Copyright @ Jurnal Gizi Prima All rights reserved.

\section{PENDAHULUAN}

Faktor risiko terjadinya berbagai penyakit metabolik salah satunya adalah masalah kegemukan dari anakanak berlanjut hingga usia dewasa (Jukes MCH et al, 2008). Data Riskesdas terdapat masalah gizi berlebih pada anak usia SD umur 7-12 tahun sebesar 18,8\%, terdiri dari gemuk 10,8\% dan sangat gemuk 8,8\% (Kemenkes, 2013). Anak usia sekolah memiliki pola makan rendah buah dan sayuran (L Endro, 2012), padahal asupan zat gizi menjadi penyebab secara langsung penentuan status gizi (UNICEF, 2016).

Sumber asupan zat gizi makro dapat terpenuhi dari berbagai bahan makanan, anak yang cukup memiliki tingkat konsumsi protein dan energi dapat memenuhi kebutuhan tubuh (Lutviana, 2010). Panduan konsumsi makanan sehari-hari terbaru di Indonesia disebut dengan isi piringku, panduan tersebut membagi piring menjadi 2 bagian dan mengisinya dengan 50\% untuk buah dan sayur (1/3 bagian buah dan 2/3 bagian untuk sayur), 50\% nya lagi dibagi 2 yaitu $1 / 3$ bagian untuk lauk pauk hewani nabati dan $2 / 3$ bagian untuk karbohidrat (Kemenkes, 2014). Anak SD menjadi sasaran kelompok masyarakat yang mudah untuk dilakukan sosialisasi isi piringku (Amrah, 2013).

Manfaat sosialisasi gizi menggunakan media komik membantu meningkatkan pengetahuan gizi dan menimbulkan motivasi diri (Cita, 2016). Penyampaian edukasi gizi anak SD dapat membentuk kebiasaan makan yang baik sejak dini (Damayanti et al., 2018). Komik menampilkan cerita bergambar yang mudah dipahami (Arroio, 2011). Perubahan sikap dan perilaku diharapkan timbul setelah adanya pemberian pengetahuan (Notoatmodjo, Soekidjo. 2011). Ketidaktahuan timbul dari media penyampaian kurang tepat. Edukasi gizi pada anak diperlukan edukasi dengan media yang edukatif, kreatif, dan inovatif (Bergmann et al. 2010). Peningkatan pengetahuan gizi dapat dilakukan melalui media komik dengan pedoman isi piringku untuk anak sekolah dasar.

\section{METODE PENELITIAN}

Desain quasi eksperiment control group pretest-posttest, menggunakan metode simple random sampling, inklusi siswa kelas 4 dan 5, berat badan berlebih, tidak sedang mendapatkan intervensi selain dari penelitian, bersedia mengikuti kegiatan sampai selesai. Pemberian edukasi isi piringku selama 4 minggu, setiap pertemuan 30-45 menit. Penelitian ini menggunakan jenis media promosi gizi, berupa komik isi piringku. Waktu penelitian dilaksanakan pada bulan Juni - Desember 2019. Lokasi penelitian di SDN 44 Ampenan, Kota Mataram dan SDN 2 Cakranegara, Kota Mataram, Nusa Tenggara Barat. Jumlah subjek 60 siswa berat badan berlebih dibagi 2 kelompok, kelompok perlakuan dan kelompok kontrol. Variabel asupan karbohidrat dan protein didapatkan dari recall $2 \times 24$ jam sebelum dan sesudah perlakuan. Data terlebih dahulu diuji normalitas data dengan uji Kolmogorov-Smirnov. Yang selanjutnya di analisis menggunakan uji paired samples t-test. Penelitian dilaksanakan setelah adanya izin dari Fakultas Kedokteran Universitas Mataram sesuai Surat Keputusan Telaah Etik Nomor: 194/UN18.F7/ETIK/2019 tanggal 2 Agustus 2019.

\section{HASIL DAN PEMBAHASAN PENELITIAN}

Tabel 1. Hasil Uji Beda Asupan Protein

\begin{tabular}{|c|c|c|c|c|c|c|}
\hline \multirow[b]{2}{*}{ Kelompok } & \multicolumn{2}{|c|}{ Sebelum } & \multicolumn{2}{|c|}{ Sesudah } & \multirow[b]{2}{*}{$\Delta$} & \multirow[b]{2}{*}{$\mathbf{p}$} \\
\hline & $\begin{array}{c}\text { (minimum } \\
+ \text { maksimum) }\end{array}$ & $($ Mean $\pm S D)$ & $\begin{array}{c}\text { (minimum } \\
+ \text { maksimum) }\end{array}$ & $($ Mean \pm SD $)$ & & \\
\hline kontrol & $38 \pm 78$ & $53,6 \pm 10,4$ & $48 \pm 75$ & $59,8 \pm 7,2$ & 6,2 & 0,011 \\
\hline perlakuan & $33 \pm 66$ & $46,5 \pm 7,8$ & $43 \pm 85$ & $63,2 \pm 8,9$ & 16,7 & 0,000 \\
\hline
\end{tabular}

Hasil uji beda memperlihatkan adanya perbedaan bermakna peningkatan asupan sumber protein sebelum dan sesudah pemberian edukasi gizi. Untuk melihat efektifitas pengaruh pemberian edukasi terhadap asupan sumber protein dilihat dari delta, kelompok kontrol mengalami peningkatan sebanyak 6,2 gram dari sebelum 
pemberian edukasi tanpa komik, sedangkan kelompok intervensi edukasi komik mengalami peningkatan asupan sumber protein yaitu 16,7 gram dari rata-rata sebelum diberikan edukasi komik isi piringku. Sejalan dengan penelitian Prabowo yang menunjukkan nilai signifikan pada asupan protein sebelum dan sesudah 2 bulan menerima pendidikan gizi (Prabowo, 2011). Ketidaktahuan timbul dikarenakan media penyampaian kurang tepat sehingga pengetahuan tidak teraplikasi dengan baik (Bergmann et al. 2010).

Jika dibandingkan dengan angka kecukupan protein yang dianjurkan untuk usia 7 - 12 tahun adalah 49 -56 gram/hari, maka tingkat kecukupan protein pada kelompok perlakuan termasuk tinggi. Telur, ayam, ikan, sumber protein hewani disukai anak-anak. Status gizi anak menjadi baik apabila konsumsi protein tinggi (Hartono, 2010). Protein dapat menyediakan energi (Adeson Trifosfat atau ATP) untuk aktivitas tubuh, protein juga dapat menyediakan alanin dan asam amino lainnya untuk dikonversi menjadi glukosa atau glikogen (Hardinsyah, 2017).

Tabel 2. Hasil Uji Beda Asupan Karbohidrat Sebelum

\begin{tabular}{|c|c|c|c|c|c|c|}
\hline \multirow[b]{2}{*}{ Kelompok } & \multicolumn{2}{|c|}{ Sebelum } & \multicolumn{2}{|c|}{ Sesudah } & \multirow[b]{2}{*}{$\Delta$} & \multirow[b]{2}{*}{$\mathbf{p}$} \\
\hline & $\begin{array}{c}\text { (minimum } \\
+ \text { maksimum) }\end{array}$ & $($ Mean \pm SD $)$ & $\begin{array}{c}\text { (minimum } \\
+ \text { maksimum) }\end{array}$ & $($ Mean \pm SD $)$ & & \\
\hline kontrol & $152 \pm 305$ & $217,6 \pm 38,6$ & $164 \pm 264$ & $204,3 \pm 23,4$ & 13,3 & 0,086 \\
\hline perlakuan & $128 \pm 258$ & $191,9 \pm 34,7$ & $140 \pm 266$ & $193,4 \pm 28,3$ & 1,5 & 0,838 \\
\hline
\end{tabular}

Hasil uji beda memperlihatkan tidak ada perbedaan bermakna asupan sumber karbohidrat sebelum dan sesudah pemberian edukasi gizi. Rata-rata asupan karbohidrat pada kelompok kontrol sebelum pemberian edukasi tanpa komik sebesar 217,6 gram dan mengalami penurunan asupan karbohidrat setelah pemberian edukasi tanpa komik menjadi 204,3 gram dengan selisih penurunan sebanyak 13,3 gram. Sesuai penelitian Schmidt, tidak terdapat perbedaan asupan karbohidrat remaja putri SMA di Michigan setelah diberikan pendidikan gizi (Rimbawan, 2004). Alasan makanan yang mengandung karbohidrat sering kali dipilih sebagai sumber utama energi, selain karena aspek kepraktisan, yaitu relatif murah, mudah diperoleh, dan mudah disimpan, juga dari aspek biologis sangat esensial menyediakan bahan dasar untuk proses-proses penting metabolisme tubuh. Sulit mengonsumsi karbohidrat dalam jumlah sedikit, tetapi sebaliknya relatif mudah mengonsumsi karbohidrat secara berlebihan hingga beresiko menyebabkan masalah kesehatan (Hardinsyah, 2017).

\section{KESIMPULAN}

Ada perbedaan bermakna pada asupan protein sesudah pemberian edukasi gizi komik isi piringku, sedangkan asupan karbohidrat tidak ada beda.

\section{SARAN}

Media pembelajaran berupa komik dapat digunakan sebagai media promosi pendidikan gizi bagi anak-anak, Peneliti dapat melanjutkan penelitian dengan seri edukasi gizi komik dengan tema lainnya.

\section{DAFTAR PUSTAKA}

Amrah. 2013. Perkembangan moral anak usia sekolah dasar. Jurnal Publikasi Pendidikan 3. 1: 20-25.

Arroio, A. 2011. Comics as a Narrative In Natural Science Education. Western Anatolia Journal of Educational Science: 93-98.

Bergmann L, Clifford D, Wolff C. 2010. Edutaintment and Teen Modeling May Spark Interest in Nutrition and Physical Activity in Elementary School Audiences. J Nutr Educ Behav: 139-141.

Choi ES, Shin NR, Jung EI, Park HR, Lee HM, Song KH. 2008. A study on nutrition knowledge and dietary behavior of el ementary school children in Seoul. Nutr Res Pract: 308-316.

Cita, D. 2014. Development of Material and Acceptance of Nutrition Education Through Visual Media on Nutrition Knowledge of Elementary School Ages. Skripsi. Bandung : Institut Pertanian Bogor. 
Damayanti AY, Fathimah, Inma YS. 2018. Gambaran Tingkat Pengetahuan Gizi Seimbang Pada Santriwati Remaja Putri di Pondok Pesantren. Darussalam Nutrition Journal Vol.2, No.2, p 1-5

Hardiansyah, I Dewa Nyoman Supariasa. 2017. Ilmu gizi: teori dan aplikasi. Jakarta: Buku Kedokteran EGC.

Jukes MCH, Drake LJ, Bundy. 2008. School Health, Nutrition and Education For All Levelling the Playing Field. CABI Internasional USA: 3-29

Kementrian Kesehatan RI. 2014. Pedoman Gizi Seimbang.Jakarta: Kemenkes RI Leaflet Isi Piringku.

Kementerian Kesehatan RI. 2013. Riset Kesehatan Dasar. Jakarta: Badan Penelitian dan Pengembangan Kesehatan.

L Endro, Damanik. 2012. Preferensi dan frekuensi konsumsi makanan jajanan pada anak sekolah dasar di Kecamatan Cijeruk, Kabupaten Bogor. Jurnal Gizi dan Pangan 7(2): 119-126.

Lutviana, Budiono. 2010. Prevalensi Dan Determinan Kejadian Gizi Kurang Pada Balita. Jurnal Kesehatan Masyarakat 5(2): 138-144.

Notoadmodjo, Soekidjo. 2011. Kesehatan Masyarakat Ilmu dan Seni. Cetakan Ke-4 Jakarta: Rineka Cipta

Prabowo, Djoeli Seto. 2011. Tesis Pengaruh Pendidikan Gizi melalui Media Komik Terhadap pengetahuan dan Asupan Energi Protein pada Anak Sekolah Dasar Dengan Kelebihan Berat Badan. Ilmu Kedokteran: Universitas Diponegoro.

Rimbawan, Siagian, Albiner. 2004. Indeks Glikemik pangan. Jakarta: Penebar Swadaya.

Simanjutak, Hartono. 2010. Konsumsi makanan jajanan, konsumsi makanan di rumah dan status gizi anak di SDN 04 Petang Jakarta Timur. Nutrire Diaita 2(1): 1-8.

UNICEF. 2016. The State Of The World's Children. 